\title{
ANALISIS EFEKTIVITAS PELUNASAN HUTANG PAJAK DI KANTOR PELAYANAN PAJAK PRATAMA BITUNG
}

\author{
Beauty Theresia Tania ${ }^{1}$, Herman Karamoy ${ }^{2}$ Sintje Rondonuwu ${ }^{3}$ \\ ${ }^{1,2,3}$ Fakultas Ekonomi dan Bisnis, Jurusan Akuntansi, Universitas Sam Ratulangi, Jl. Kampus Bahu, Manado, \\ 95115, Indonesia \\ E-mail : byutania@gmail.com
}

\begin{abstract}
Tax liability represents accrued taxes including administrative sanctions in the form of interest, penalty or increment stipulated in tax assessment letters or similar letters under the provisions of the transitional tax laws. Implementation of tax liability in Bitung City is caused by external factors of taxpayers and internal factors of the fiskus (Tax Officers). This study aims to determine the effectiveness of tax repayment in KPP Pratama Bitung. The method of analysis used in this research is descriptive qualitative by using ratio of effectiveness ratio. The results of the researchand analysis show that the repayment of tax debt in KPP Pratama Bitung can be seen from the year 2013, 2014, 2015 the realization of the tax debt repayment did not reach the target and ini 2016, 2017 the realization of the debt repayment past the expected target. Based on the results of the analysis, the repayment of tax debt in KPP Pratama Bitung in 2013 is quite effetive, 2014 and 2015 ineffective, 2016 and 2017 are very effective..
\end{abstract}

Keywords: Effectiveness, Tax Payable

\section{PENDAHULUAN}

Pajak digunakan sebagai salah satu usaha yang digunakan oleh pemerintah untuk mewujudkan kemandirian suatu bangsa atau negara dalam pembiayaan pembangunan yang berguna bagi kepentingan bersama (Khasanah, 2014). Fungsi utama dari pajak adalah untuk meningkatkan pendapatan suatu negara, gunanya adalah untuk membiayai pengeluaran penting pada barang dan jasa yang disediakan oleh pemerintah (Okoye \& Ezejiofor, 2014). Pajak merupakan salah satu modal untuk membiayai aktivitas pemerintah dalam menjalankan pembangunan. Pernyataan tersebut selaras dengan yang dikatakan oleh (Attawodi \& Ojeka, 2012) "Tax is an important stream of revenue for government's development projects.

Peran serta masyarakat (wajib pajak) dalam memenuhi kewajiban pembayaran pajak berdasarkan ketentuan perpajakan sangat diharapkan. Namun, dalam kenyataan dijumpai sering adanya tunggakan pajak atau hutang pajak, terlebih lagi bila dari waktu ke waktu menunjukan jumlah yang semakin besar maka diperlukan penanganan yang lebih serius. Artinya, walaupun penerimaan pajak secara umum meningkat, tetapi terhadap tunggakan atau hutang pajak diperlukan tindakan penagihan yang tegas sesuai dengan ketetentuan undangundang perpajakan.

Hutang pajak yang terjadi di KPP disebabkan karena kurangnya kesadaran pemahaman akan kewajibannya dalam melaksanakan peran perpajakan mengakibatkan fiskus harus menetapkan besarnya jumlah pajak yang harus dibayar oleh wajib pajak, besarnya ketetapan pajak yang ditentukan oleh fiskus menyebabkan meningkatnya tunggakan pajak.Wajib pajak dikatakan patuh apabila dapat memenuhi dan melaksanakan kewajiban perpajakan. Kepatuhan wajib pajak tersebut berupa: tepat waktu membayar pajak dan membayar sesuai dengan besarannya serta mengikuti perkembangan undang-undang perpajakan yang berlaku (Annisa,2016). 
Menurut Undang-Undang Nomor 19 Tahun 2000 definisi utang pajak merupakan pajak yang masih harus dibayar termasuk sanksi administrasi berupa bunga, denda atau kenaikan yang tercantum dalam surat ketetapan pajak atau surat sejenisnya berdasarkan ketentuan peralihan perundang-undangan perpajakan. Undang-Undang Pajak Nomor 19 Tahun 2000 adalah dasar hukum mengenai hutang pajak.

Kantor Pelayanan Pajak (KPP) adalah unit kerja dari Dirtjen Pajak yang melaksanakan pelayanan kepada masyarakat baik yang terdaftar sebagai wajib pajak maupun yang tidak. Kantor Pelayanan Pajak Pratama Bitung adalah salah satu kantor pelayanan pajak modern yang ada di Provinsi Sulawesi Utara yang diresmikan tanggal 24 November 2008 yang dibentuk dari gabungan Kantor Pelayanan Pajak Kota Manado. Dengan terus melaksanakan penagihan dalam rangka meningkatkan peneriman pajak dan meminimalisir jumlah hutang pajak di wilayah kerjanya maka KPP Pratama Bitung berharap agar penerimaan pajak terus bertambah sehingga pelunasan hutang pajak dapat berjalan efektif.

Pelaksanaan pelunasan hutang pajak yang terjadi di Kota Bitung disebabkan oleh faktor eksternal yaitu wajib pajak dan faktor internal dari pihak Fiskus (Pejabat Pajak). Apabila pelunasan hutang pajak berjalan efektif diharapkan dapat mempengaruhi peningkatan penerimaan pajak di daerah setempat. Namun, apabila pelunasan hutang pajak berjalan tidak efekif hal tersebut dipengaruhi oleh kendala yang disebabkan dari pihak Wajib Pajak maupun Fiskus (Pejabat Pajak).

\section{TINJAUAN PUSTAKA}

\subsection{Konsep Akuntansi}

Menurut Suwardjono (2013:5) akuntansi adalah seni pencatatan, penggolongan, dan peringkasan transaksi dan kejadian yang bersifat keuangan dengan cara yang berdaya guna dan dalam bentuk satuan uang, dan penginterpretasian hasil proses tersebut. Accounting is the art of recording, classifying, and summarizing in a significant manner and in terms of money transactions (Gashemi \& Aslani, 2011).

\subsection{Konsep Perpajakan}

\subsubsection{Pengertian Pajak}

Pajak adalah iuran kepada negara (yang dapat dipaksakan) yang terutang oleh yang wajib membayarnya menurut peraturan-peraturan, dengan tidak mendapat prestasi kembali, yang langsung dapat ditunjuk, dan yang gunanya adalah untuk membiayai pengeluaranpengeluaran umum berhubung tugas negara untuk menyelenggarakan pemerintahan (Adriani dalam buku Sumarsan, 2013 : 3). Sedangkan menurut Miller \& Oast (2012: 3) pajak adalah sistem pemungutan wajib atau pemerasan yang dikenakan untuk membiayai belanja publik.

\subsubsection{Fungsi Pajak}

Terdapat 2 fungsi pajak yang dikemukakan oleh Mardiasmo, 2016: 4 dalam bukunya, yaitu :

1. Fungsi anggaran (budgetair)

2. Fungsi mengatur (regulerend)

\subsubsection{Pengelompokan Pajak}

Menurut Supramono (2015:10) pajak dapat dikelompokan ke dalam tiga kelompok, yaitu pajak menurut golongannya, menurut sifatnya dan menurut lembaga pemungutannya yang masing-masing diuraikan sebagai berikut :

1. Menurut golongannya

2. Menurut sifatnya

3. Menurut lembaga pemungutnya

\subsubsection{Asas Pemungutan Pajak}

Asas pemungutan pajak yang diungkapkan Waluyo (2011: 16) sebagai berikut:

1. Asas Tempat Tinggal 
Negara-negara mempunyai hak untuk memungut atas seluruh pengasilan wajib pajak. Wajib Pajak yang bertempat tinggal di Indonesia dikenai pajak atas penghasilan yang diterima atau diperoleh, yang berasal dari Indonesia atau berasal dari luar negeri.

2. Asas Kebangsaan

Pengenaan pajak dihubungkan dengan suatu negara. Asas ini diberlakukan kepada setiap orang asing yang bertempat tinggal di Indonesia untuk membayar pajak.

3. Asas Sumber

Negara mempunyai hak untuk memungut pajak atas pengasilan yang bersumber pada suatu negara yang memungut pajak. Dengan demikian, Wajib Pajak menerima atau memperoleh pengasilan dari Indonesia dikenakan pajak di Indonesia tanpa memperhatikan tempat tinggal Wajib Pajak.

\subsubsection{Sistem Pemungutan Pajak}

Terdapat tiga macam sistem pemungutan pajak (Mardiasmo 2016: 9-10) :

a. Official Assessment System

Official Assessment System adalah sistem pemungutan pajak yang memberikan wewenang kepada pemerintah (fiskus) untuk menentukan besarnya pajak yang terutang oleh Wajib Pajak.

b. Self Assessment System

Self Assessment System adalah sistem pemungutan pajak yang memberi wewenang kepada Wajib Pajak untuk menentukan sendiri besarnya pajak yang terutang.

c. Withholding System

Withholding System adalah sistem pemungutan pajak yang memberi wewenang kepada pihak ketiga (bukan fiskus dan bukan wajib pajak yang bersangkutan) untuk memotong atau memungut pajak yang terutang oleh wajib pajak.

\subsubsection{Syarat Pemungutan Pajak}

Agar Pemungutan pajak tidak menimbulkan hambatan atau halangan, maka pemungutan pajak harus memenuhi syarat sebagai berikut (Mardiasmo 2016:4-5):

1. Pemungutan pajak harus adil (Syarat Keadilan)

2. Pemungutan pajak harus berdasarkan undang-undang (Syarat Yuridis) Di Indonesia, pajak diatur dalam UUD 1945 pasal 23 ayat 2.

3. Tidak mengganggu perekonomian (Syarat Ekonomis)

4. Pemungutan pajak harus efisien (Syarat Finansiil)

5. Sistem pemungutan pajak harus sederhana

\subsubsection{Teori-teori yang Mendukung Pemungutan Pajak}

Dalam Mardiasmo (2016:5-6), terdapat beberapa teori yang menjelaskan atau memberikan justifikasi pemberian hak kepada negara untuk memungut pajak. Teoriteori tersebut antara lain sebagai berikut:

1. Teori Asuransi

2. Teori Kepentingan

3. Teori Daya Pikul

\subsubsection{Hambatan Pemungutan Pajak}

Dalam Mardiasmo (2016:10-11) hambatan terhadap pemungutan pajak dapat dikelompokkan sebagai berikut:

1. Perlawanan Pasif

Masyarakat dengan enggan (pasif) membayar pajak, yang dapat disebabkan antara lain:

a. Perkembangan intelektual dan moral masyarakat.

b. Sistem perpajakan yang (mungkin) sulit dipahami masyarakat.

c. Sistem kontrol tidak dapat dilakukan atau dilaksanakan dengan baik. 


\section{Perlawanan Aktif}

Perlawanan aktif meliputi semua usaha dan perbuatan yang secara langsung ditujukan kepada fiskus dengan tujuan untuk menghindari pajak. Bentuknya antara lain:

a. Tax avoidance, usaha meringankan beban pajak dengan tidak melanggar undangundang.

b. Tax evasion, usaha meringankan beban pajak dengan cara melanggar undangundang (menggelapkan pajak).

\subsubsection{Stelsel Pajak}

Terdapat 3 stelsel yang dapat dilakukan dalam pemungutan pajak seperti yang dikemukakan oleh Mardiasmo, 2016: 8 dalam bukunya, yaitu :

1. Stelsel nyata (riel stelsel)

2. Stelsel anggapan (fictieve stelsel)

3. Stelsel campuran

\subsubsection{Jenis-jenis Pajak}

Ditinjau dari sudut lembaga yang memungut pajak, maka kita bisa membagi jenis pajak menjadi dua jenis yaitu (Mardiasmo, $2016: 8$ ).

a. Pajak Pusat

b. Pajak Daerah

1. Pajak Propinsi, contoh : Bea Balik Nama Kendaraan Bermotor; Pajak Bahan Bakar Kendaraan Bermotor; Pajak Kendaraan Bermotor; Pajak Rokok dan Pajak Air Permukaan;

2. Pajak Kabupaten/Kota, contoh : Pajak Restoran;Pajak Hotel;Pajak Penerangan Jalan;Pajak Hiburan;Pajak Mineral Bukan Logam dan Batuan;Pajak Reklame;Pajak Parkir;Bea Perolehan Hak atas Tanah dan Bangunan.Pajak Air Tanah;Pajak Sarang Burung Walet;Pajak Bumi dan Bangunan Perdesaan dan Perkotaan.

\subsection{Konsep Akuntansi Perpajakan}

\subsubsection{Akuntansi Pajak}

Dalam bukunya "Akuntansi Perpajakan" Supriyanto Eddy (2011:2) menyatakan bahwa: Akuntansi pajak adalah suatu proses pencatatan, penggolongan dan pengikhtisaran suatu transaksi keuangan kaitannya dengan kewajiban perpajakan dan diakhiri dengan pembuatan laporan keuangan fiskal sesuai dengan peraturan perpajakan yang terkait sebagai dasar pembuatan surat pemberitahuan tahunan".

\subsection{Penagihan Pajak}

Dirjen Pajak dapat melakukan tindakan penagihan pajak, apabila jumlah pajak yang terutang berdasarkan Surat Tagihan Pajak (STP), Surat Ketetapan Pajak Kurang Bayar (SKPKB), serta Surat Ketetapan Pajak Kurang Bayar Tambahan (SKPKBT), dan Surat Keputusan Pembetulan, Surat Keputusan Keberatan, Putusan Banding, serta Putusan Peninjauan Kembali, yang menyebabkan jumlah pajak yang masih harus dibayar bertambah untuk Pajak Penghasilan $(\mathrm{PPh})$ serta Pajak Pertambahan Nilai (PPn) dan Pajak Penjualan atas Barang Mewah (PPnBM) tidak dibayar oleh penanggung pajak sesuai dengan jangka waktu yang ditetapkan dalam peraturan perundang-undangan perpajakan (TMBooks, 2015:58).

\subsubsection{Dasar Hukum Penagihan Pajak}

Menurut Widyaningsih (2013:206) dasar hukum penagihan pajak yang melandasi yaitu :

1. Undang-undang Nomor 6 Tahun 1983 Tentang Ketentuan Umum Dan Tata Cara Perpajakan sebagaimana telah diubah terakhirdengan UU Nomor 16 Tahun 2009.

2. Undang-undang Nomor 19 Tahun 2000 Tentang Penagihan Pajak Dengan Surat Paksa. 
3. Peraturan Pemerintah Nomor 74 Tahun 2011 tentang Tata Cara Pelaksanaan Hak Dan Pemenuhan Kewajiban Perpajakan

4. Peraturan Menteri Keuangan Nomor 85/PMK.03/2010 tentang Perubahan Atas Peraturan Menteri Keuangan Nomor 24/PMK.03/2008 tentang Tata Cara Pelaksanaan Penagihan dengan Surat Paksa dan Pelaksanaan Penagihan Seketika dan Sekaligus.

\subsubsection{Dasar Tindakan Penagihan Pajak}

Mengacu pada ketentuan pasal 18 ayat 1 Undang-Undang Nomor 28 Tahun 2009 (UU KUP), penagihan pajak akan dilakukan apabila terdapat utang pajak yang dapat ditagih dengan:

1. Surat Tagihan Pajak (STP)

2. Surat Ketetapan Pajak (SKP)

3. Surat Keputusan Pembetulan

4. Surat Keputusan Keberatan

5. Putusan Banding dan Putusan Peninjauan Kembali

\subsubsection{Tindakan Penagihan Pajak}

Penagihan Pajak menurut Rosdina (2011:254) adalah serangkaian tindakan agar Penanggung Pajak melunasi utang pajak dan biaya penagihan pajak dengan menegur atau memerintahkan, melaksanakan penagihan seketika dan sekaligus, memberitahukan surat paksa, mengusulkan pencegahan, melaksanakan penyitaan, melaksanakan penyanderaan, dan menjual barang yang telah disita.

\subsubsection{Tahapan Penagihan Pajak Aktif}

Apabila wajib pajak tidak membayar pajak sesuai dengan ketentuan atau membayar pajak tidak sebagaimana mestinya maka dilakukan tindakan penagihan pajak oleh fiskus. Hal ini dimaksudkan agar wajib pajak membayar pajak sesuai dengan ketentuan yang berlaku.

\subsubsection{Daluwarsa Penagihan Pajak}

Apabila telah daluwarsa penagihan, maka penagihan pajak tidak dapat dilaksanakan lagi sebagaimana diatur dalam undang-undang, karena hak untuk melakukan penagihan atas utang pajak tersebut telah gugur. Hak untuk melakukan penagihan pajak, termasuk bunga, denda, kenaikan dan biaya penagihan pajak, daluwarsa setelah melampaui waktu (lima) tahun terhitung sejak penerbitan saat terutangnya pajak atau berakhirnya masa pajak, Bagian Surat Tagihan Pajak, Surat Ketetapan Pajak Kurang Bayar, serta Surat Ketetapan Kurang Bayar Tambahan, dan Surat Keputusan Pembetulan, Surat Keputusan Keberatan, Putusan Banding, serta Surat Putusan Peninjauan Kembali (Sumarsan, 2013:71).

\subsubsection{Tarif Pajak}

Ada 4 macam tarif pajak dalam Mardiasmo (2016:11-12):

1. Tarif sebanding/proporsional

Tarif berupa presentase yang tetap, terhadap berapapun jumlah yang dikenai pajak sehingga besarnya pajak yang terutang proporsional terhadap besarnya nilai yang dikenai pajak.

Contoh: Untuk penyerahan Barang Kena Pajak di dalam daerah pabean akan dikenakan Pajak Pertambahan Nilai sebesar $10 \%$.

2. Tarif tetap

Tarif berupa jumlah yang tetap (sama) terhadap berapapun jumlah yang dikenai pajak sehingga besarnya pajak yang terutang tetap. Contoh: Besarnya tarif Bea Materai untuk cek dan bilyet giro dengan nilai nominal berapapun adalah $\operatorname{Rp} 3.000,00$.

3. Tarif progresif 
Presentase tarif yang digunakan semakin besar bila jumlah yang dikenai pajak semakin besar. Contoh: pasal 17 Undang-undang Pajak Penghasilan untuk Wajib Pajak orang pribadi dalam negeri.

\subsection{Utang Pajak}

Pada umumnya, secara konseptual, kewajiban perpajakan muncul dan terutang apabila terpenuhinya kondisi dan syarat yang didefinisikan oleh ketentuan peraturan perundang-undangan perpajakan. Jika kewajiban tersebut muncul maka harus ada instrumen administrasi yang menunjukkannya, misalnya bagi pemotong pajak harus membuat bukti pemotongan. Jika kewajiban perpajakan muncul, selain wajib membuat instrumen administrasi yang menunjukkannya, Wajib Pajak wajib membuat pencatatan atau pembukuannya, yang dikenal sebagai akuntansi perpajakan (Sari, 2013:47).

\subsubsection{Timbulnya Utang Pajak}

Dalam Mardiasmo (2016:10) ajaran yang mengatur timbulnya utang pajak (saat pengakuan adanya utang pajak) sebagai berikut.

1. Ajaran Formil, ajaran ini menyatakan bahwa utang pajak timbul karena diberlakukannya surat ketetapan pajak. Ajaran ini diterapkan pada official assessment system.

2. Ajaran Materiil, ajaran ini menyatakan bahwa utang pajak timbul karena berlakunya undang-undang. Seseorang dikenai pajak karena suatu keadaan dan perbuatan. Ajaran ini diterapkan pada self assessment system.

\subsubsection{Hapus atau Berakhirnya Utang Pajak}

Dalam Sari (2013:49), hapusnya utang pajak disebabkan beberapa hal sebagai berikut:

1. Pembayaran

Hutang pajak akan dihapus apabila telah dibayar lunas sesuai dengan tata cara yang ditentukan dalam perpajakan ataupun sesuai dengan ketentuan Undang-Undang perpajakan.

2. Kompensasi

Yaitu cara pelunasan utang pajak dengan memperhitungkan kelebihan pembayaran pajak terhadap utang pajak lainnya.

3. Pembebasan

Pembebasan yang diberikan pemerintah kepada wajib pajak berdasarkan suatu alas an tertentu yang logis, artinya memenuhi syarat-syarat yang ditentukan oleh UndangUndang untuk diberikan pembebasan dan dipertegas denga Surat Keputusan Pembebasan dari Dirjen Pajak.

4. Daluwarsa

Yaitu hapusnya suatu perikatan (hak menagih hutang; kewajiban membayar hutang), karena lampaunya jangka waktu tertentu sesuai dengan ketentuan yang ditetapkan dalam Undang-Undang. Maksud daluwarsa, yaitu untuk mengakhiri suatu keadaan yang tidak menentu.

\subsection{Pejabat dan Juru SitaPajak}

Pejabat dalam Pasal 1 Peraturan Pemerintah No. 135 tahun 2000 adalah orang yang berwenang mengangkat dan memberhentikan Juru Sita Pajak, menerbitkan surat Perintah Penagihan Seketika dan Sekaligus, Surat Paksa, Surat Perintah Melaksanakan Penyitaan (SPMP), Surat Pencabutan Sita, Pengumuman Lelang, Surat Penentuan Harga Limit, Pembatalan Lelang, Surat Perintah Penyanderaan dan surat lainnya yang diperlikan untuk penagihan sehubungan dengan Penanggung Pajak tidak melunasi sebagian atau seluruh utang pajak menurut Undang-Undang dan Peraturan Daerah. 


\subsection{Konsep Efektivitas}

Pelaksanaan pencairan tunggakan pajak dengan menggunakan biaya yang sedikit merupakan salah satu faktor pendukung dalam pencapaian efektivitas. Pernyataan tersebut selaras dengan (Leos, 2002) effectiveness can be consider as ability of government to collect taxes with low costs.

\subsection{Penelitian Terdahulu}

Tingkan Larosa Ursula Walewangko tahun 2016 dengan judul Analisis Efektivitas Penagihan Pajak Aktif dengan Tindakan Penyitaan Terhadap Pencairan Tunggakan Pajak di Kantor Pelayanan Pajak Pratama Ambon. Hasil penelitian Penagihan pajak dengan tindakan penyitaan/SPMP pada KPP Pratama Ambon tidak efektif.

Azriel Alam tahun 2016 dengan judul Pengaruh Penerbitan Surat Teguran, Surat Paksa, dan Surat Perintah Melaksanakan Penyitaan Terhadap Pencairan Tunggakan Pajak. Hasil penelitian Surat teguran, surat paksa, dan SPMP berpengaruh secara simultan terhadap pencairan tunggakan pajak pada KPP Pratama Pabean Cantikan Surabaya.

\section{METODE PENELITIAN}

3.1 Jenis Penelitian

Penelitian ini menggunakan jenis penelitian kualitatif deskriptif dimana peneliti secara langsung mendatangi objek penelitian yaitu Kantor Pelayanan Pajak Pratama Bitung untuk memperoleh data-data dan informasi yang dibutuhkan dalam menganalisis efektivitas pelunasan hutang pajak. Sugiyono (2014:22) metode deskriptif adalah metode yang digunakan untuk menggambarkan atau menganalisis suatu hasil penelitian tetapi tidak digunakan untuk membuat kesimpulan yang lebih luas.

\subsection{Tempat Dan Waktu Penelitian}

Penelitian ini dilakukan pada Kantor Pelayanan Pajak Pratama Bitung jalan Sam Ratulangi, Bitung Barat II, Maesa, Bitung Tengah, Kota Bitung, Sulawesi Utara. Waktu penelitian dimulai dari bulan Juli sampai dengan bulan Desember.

\subsection{Prosedur Penelitian}

Adapun prosedur penelitian yang digunakan dalam skripsi ini adalah :

1. Survei Pendahuluan

2. Identifikasi Objek

3. Pengumpulan Data

4. Analisis Data

5. Kesimpulan dan Saran

\subsection{Metode Pengumpulan Data}

\subsubsection{Jenis Data}

Penelitian terbagi menjadi dua bagian yaitu sebagai berikut:

1. Data Kualitatif

2. Data kuantitaif

\subsubsection{Sumber Data}

Data primer yang dihasilkan dalam penelitian ini adalah hasil wawancara langsung dengan pihak Kantor Pelayan Pajak Pratama Bitung. Data sekunder hasil studi kepustakaan dengan mengumpulkan serta mempelajari teori-teori yang dapat mendukung penelitian ini.

\subsubsection{Teknik Pengumpulan Data}

1. Teknik Wawancara

2. Teknik Dokumentasi 


\subsection{Metode Analisis}

Metode analisis yang digunakan dalam penelitian ini adalah deskriptif. Penelitian deskriptif adalah suatu metode yang bertujuan untuk membuat deskripsi, gambaran suatu keadaan secara sistematis, faktual dan akurat mengenai fakta-fakta, sifat-sifat serta hubungan antar fenomena yang diselidiki. Penelitian deskriptif yang dilakukan dengan wawancara, Tanya jawab langsung dengan pihak-pihak yang bersangkutan di Kantor Pelayanan Pajak Pratama Bitung sehubungan dengan efektivitas pelunasan hutang pajak.

\section{HASIL ANALISIS DAN PEMBAHASAN}

\subsection{Hasil Penelitian}

\subsubsection{Pelunasan Hutang Pajak Tahun 2013-2017 di KPP Pratama Bitung}

Berdasarkan data di atas dapat diketahui bahwa pada tahun 2013 target pelunasan hutang pajak di KPP Pratama Bitung sebesar Rp 1.723.765.465.00 dan yang terealisasikan tidak sesuai jumlah yang ditetapkan yaitu sebesar Rp 1.536.759.456.00

Target Pelunasan hutang pajak di KPP Pratama Bitung pada tahun 2014 sebesar Rp 39.832.593.495 dan yang terealisasikan tidak sesuai jumlah yang ditetapkan yaitu sebesar $\mathrm{Rp} 22.635 .184 .133$

Pada tahun 2015 target pelunasan hutang pajak di KPP Pratama Bitung sebesar Rp 61.365.148.534 dan jumlah yang teralisasikan tidak sesuai yang ditetapkan yaitu sebesar Rp 31.526.851.456.

Target Pelunasan hutang pajak di KPP Pratama bitung pada tahun 2016 yaitu sebesar Rp 1.660.366.620.00 dan yang terealisasikan melebihi jumlah yang ditetapkan yaitu sebesar Rp 195.890.053.828

Pada Tahun 2017 target pelunasan hutang pajak sebesar Rp 3.121.977.472 dan yang terealisasikan sebesar Rp 40.808.171.988.

Wajib pajak yang tidak membayar pajak tepat pada waktunya maka saat itu juga Wajib Pajak memiliki tunggakan pajak. KPP Pratama Bitung menyadari tidak semua tunggakan pajak yang tercatat dapat tertagih. Faktor-faktor yang menyebabkan tunggakan pajak tidak tertagih yaitu seperti wajib pajak mengajukan keberatan, mengajukan banding, atau wajib pajak tidak ditemukan. Penagihan pajak pada KPP Pratama Bitung mengalami kenaikan disetiap tahunnya, hal ini tentunya berpengaruh pada jumlah penerimaan pajak.

\subsection{Pembahasan}

\subsubsection{Efektivitas Pelunasan Hutang Pajak}

Berdasarkan tabel 4.3 diatas dapat diketahui bahwa pada tahun 2013 target pelunasan hutang pajak di KPP Pratama Bitung sebesar Rp 1.723.765.465.00 dan jumlah yang dibayar oleh wajib pajak sebesar Rp 1.536.759.456.00 atau sekitar $89,15 \%$. Berdasarkan indikator pengukuran tingkat efektivitas pelunasan hutang pajak tahun 2013 menunjukaan cukup efektif. Hal ini dilihat berdasarkan klasifikasi indikator keefektivan yang menunjkkan bahwa presentase keefektivan kurang dari $80 \%$. Hal-hal yang menyebabkan pelunasan hutang pajak cukup efektif yaitu Juru Sita Pajak kesulitan dalam menemukan alamat Wajib Pajak karena Wajib Pajak yang bersangkutan sudah pindah alamat namun tidak memberitahukan kepada pihak KPP serta kurangnya jumlah Juru Sita Pajak.

Pada tahun 2014 menunjukkan bahwa target penagihan pajak sebesar Rp 39.832.593.495 dan jumlah yang dibayar oleh wajib pajak sebesar Rp 22.635.184.133 atau sekitar $56,82 \%$. Berdasarkan indikator pengukuran tingkat efektivitas pelunasan hutang pajak tahun 2014 tergolong tidak efektif. Hal ini dilihat berdasarkan 
klasifikasi indikator keefektivan yang menunjukkan bahwa presentase keefektivan kurang dari $60 \%$. Hal-hal yang menyebabkan pelunasan hutang pajak tidak efektif yaitu Juru Sita Pajak kesulitan dalam menemukan alamat Wajib Pajak karena Wajib Pajak yang bersangkutan sudah pindah alamat namun tidak memberitahukan kepada pihak KPP dan terjadi kebangkrutan atau pembubaran perusahaan atau badan sehingga tidak diketahui keberadaannya.

Pada tahun 2015 menunjukkan bahwa target penagihan pajak sebesar $\mathrm{Rp}$ 61.365.148.534 dan jumlah yang dibayar oleh wajib pajak sebesar Rp 31.526.851.456 atau sekitar 51,37\%. Berdasarkan indikator pengukuran tingkat efektivitas mekanisme penyitaan pajak tahun 2015 tergolong tidak efektif. Hal ini dilihat berdasarkan klasifikasi indikator keefektivan yang menunjukkan bahwa presentase keefektivan kurang dari 60\%. Hal-hal yang menyebabkan pelunasan hutang pajak tidak efektif yaitu Juru Sita Pajak kesulitan dalam menemukan alamat Wajib Pajak karena Wajib Pajak yang bersangkutan sudah pindah alamat namun tidak memberitahukan kepada pihak KPP, terjadi kebangkrutan atau pembubaran perusahaan atau badan sehingga tidak diketahui keberadaannya dan jumlah barang yang disita tidak memenuhi jumlah utang pajak yang terutang.

Pada tahun 2016 menunjukkan bahwa target penagihan pajak sebesar Rp 1.660.366.620.00 dan jumlah yang dibayar oleh wajib pajak sebesar Rp 195.890.053.828 atau sekitar 117,98\%. Berdasarkan indikator pengukuran tingkat efektivitas pelunasan hutang pajak tahun 2016 menunjukan sangat efektif. Hal ini dilihat berdasarkan klasifikasi indikator keefektivan yang menunjukkan bahwa presentase keefektivan lebih dari $100 \%$. Pada tahun ini wajib pajak telah melunasi hutang-hutangnya dengan sangat baik. Kendala yang dihadapi juga tidak ditemukan.

Pada tahun 2017 menunjukkan bahwa target penagihan pajak sebesarRp 3.121.977.472 dan jumlah yang dibayar oleh wajib pajak sebesar Rp 40.808.171.988 atau sekitar $1.307,12 \%$. Berdasarkan indikator pengukuran tingkat efektivitas pelunasan hutang pajak tahun 2017 menunjukan sangat efektif. Hal ini dilihat berdasarkan klasifikasi indikator keefektivan yang menunjukkan bahwa presentase keefektivan lebih dari $100 \%$. Pada tahun ini wajib pajak telah melunasi hutanghutangnya dengan sangat baik. Kendala yang dihadapi juga tidak ada. Hal itu disebabkan karena Wajib Pajak sudah melunasi sebelum jatuh tempo pelunasan.

Berdasarkan hasil pengolahan data yang tercantum di atas dapat dilihat bahwa selama lima tahun terakhir mengalami kenaikan dan penurunan di setiap tahunnya, dapat dilihat pada tahun 2013, 2014, 2015 realisasi pelunasan hutang pajak tidak mencapai target dan pada tahun 2016, 2017 realisasi pelunasan hutang pajak melewati target yang diharapkan.

\section{KESIMPULAN DAN SARAN}

\subsection{Kesimpulan}

1. Pelunasan hutang pajak di KPP Pratama Bitung selama lima tahun terakhir mengalami pasang surut, dapat dilihat pada tahun 2013, 2014, 2015 realisasi pelunasan hutang pajak tidak mencapai target dan pada tahun 2016 dan 2017 realisasi pelunasan hutang pajak melewati target yang diharapkan.

2. Pada tahun 2013 tingkat keefektivan sebesar $\%$ menunjukan cukup efektif. Pada tahun 2014 tingkat keefektivan sebesar 56,82\% dan tahun 2015 tingkat keefektivan sebesar 51,37\% menujukan tidak efektif. Pada tahun 2016 tingkat keefektivan sebesar $117,98 \%$ dan tahun 2017 tingkat keefektivan sebesar $1.307,12 \%$ menunjukan sangat efektif. 
3. Hal-hal yang menyebabkan pelunasan hutang pajak cukup efektif bahkan tidak efektif yaitu sikap wajib pajak yang tidak patuh, wajib pajak yang tidak di temukan, wajib pajak yang tidak mengerti aturan, wajib pajak yang sudah mempunyai NPWP dianggap sudah mengetahui tentang pajak tetapi dari segi wajib pajak yang berkendala dalam kondisi keuangan, wajib pajak yang tidak mengakui adanya utang pajak, Terjadi kebangkrutan atau pembubaran perusahaan atau badan sehingga tidak diketahui keberadaannya, Juru Sita Pajak kesulitan dalam menemukan alamat wajib pajak, kurangnya juru sita pajak di KPP Pratama

\subsection{Saran} Bitung.

Saran dari penelitian ini :

1. Direktorat Jenderal Pajak agar lebih meningkatkan sosialisasi kepada wajib pajak tentang hak dan kewajiban wajib pajak serta adanya sanksi yang tegas agar supaya wajib pajak tidak lalai dalam membayar pajak.

2. KPP Pratama Bitung sebaiknya menambah staf Jurusita Pajak, karena mengingat bahwa tidak sedikit wajib pajak yang akan dihadapi dan mengingat bahwa target pelunasan hutang pajak meningkat setiap tahunnya, hal ini dilakukan agar supaya proses pelunasan hutang pajak bisa berjalan lebih efektif dan efisien.

3. Upaya dalam melaksanan penagihan harus lebih diidentifikasi agar supaya target pajak yang ditetapkan bisa terealisasi dengan baik. Karena semakin efektif tingkat pelunasan hutang pajak, maka akan semakin meningkat penerimaan pajak. Sebaliknya, semakin tidak efektif pelunasan hutang pajak maka semakin rendah pula tingkat penerimaan pajak.

4. Meningkatkan pelayanan yang nyaman serta pemahaman mengenai aturan perpajakna yang telah ditetapkan.

5. Bagi peneliti selanjutnya diharapkan dapat memperluas dan mengembangkan ruang lingkup penelitian.

\section{DAFTAR PUSTAKA}

Adriani, 2013. Dasar-dasar Perpajakan. Penerbit Pustaka Universitas Terbuka Jakarta

Alam, Azriel. 2016. Pengaruh Penerbitan Surat Teguran, Surat Paksa, dan Surat Perintah Melaksanakan Penyitaan Terhadap Pencairan Tunggakan Pajak. Skripsi Fakultas Ekonomi dan Bisnis. Universitas Hasanudin. Makassar.

Annisa, Nur. 2016. Implementasi Sistem Withholding Tax Terhadap Pajak Penghasilan (PPh) pada Bank Muamalat Indonesia KCP Tulungagung dan Bank Jatim Cabang Syariah Kediri. Insitut Agama Islam Negeri Tulungagung.

Madjid, Olvi. 2016. Efektifitas Penagihan Pajak dengan Surat Teguran dan Surat Paksa terhadap Penerimaan Pajak Penghasilan Pada Kntor Pelayanan Pajak Pratama Bitung. Skripsi Fakultas Ekonomi dan Bisnis.Universitas Sam Ratulangi. Manado

Attawodi, Ojochogwu Winnie \& Ojeka, Stephen Aanu. 2012. Factors That Affect Tax Compliance among Small and Medium Enterprises (SMEs) in North Central Nigeria. International Journal Of Business and Management Toronto. Vol. VII Issue 12 ISSN: 1833-3850.

Hanum, Zulia. 2015. Analisis Pengendalian Intern Penyitaan Asset Wajib Pajak Pada KPP Pratama Medan Polonia. Jurnal SNEMA. 2015. Universitas Negeri Padang

Hery. 2014. Akuntansi Perpajakan. PT.Grasindo. Jakarta. 
Hongren Harisson, 2012, Accounting. Pearson International Edition. Upper Saddle, New Jersey.

Khasanah, Septiyani, Nur. 2014. Pengaruh Pengetahuan Perpajakan, Modernisasi Sistem Administrasi Perpajakan, dan Kesadaran Wajib Pajak Terhadap Kepatuhan Wajib Pajak pada Kantor Wilayah Direktorat Jenderal Pajak Daerah Istimewa Yogyakarta Tahun 2013. Universitas Negeri Yogyakarta.

Kieso, Donald E., Jerry J. Weygandt, Paul D.Kimmel, 2012. Financial and Managerial Accounting, Volume 1. United States of America.

Kiswanto, 2014. "Faktor-faktor yang Mempengaruhi Penerimaan Paja" Accounting Analysis Journal, Vol. 3, No. 2, 2014

Kristianti Eka, 2015. Tingkat Pencapaian Target dan Efisiensi Pendapatan Asli Daerah (PAD) Kota Salatiga. Jurnal Akuntansi Vol.4 No.2. Universitas Kristen Satya Wacana. Salatiga. 